Nutrition is an integral part of the prevention and management of the most prevalent conditions faced by today's primary care providers.

This book is aimed at physicians around the world who treat patients from all walks of life. The first section is devoted to the basic principles of nutrition, covering the fundamentals of body composition, energy balance, and appetite, as well as the importance of the different macroand micronutrients. The following section builds on the principles of the first by focusing on the special needs for specific circumstances, including pregnancy, exercise, food allergies and religion. The third part provides an overview of our latest understanding of various disease states and how they are influenced by nutrition. The final part on Food Policy takes a bird's eye view, offering perspectives on global sustainability, the rapidly changing face of malnutrition and the role played by the food industry in consumer health.

This book is a practical reference source that will guide physicians on how to use nutrition as a tool to prevent and cure disease.

Nestlé Nutrition Institute Workshop Series, Vol. 79

Nutrition, Gut Microbiota and Immunity: Therapeutic Targets for IBD

Editors: Lewis, J.D. (Philadelphia, Pa.);

Ruemmele, F.M. (Paris); Wu, G.D. (Philadelphia, Pa.) XIV + 166 p., 14 fig., 11 tab., 2014

CHF 50.00 / EUR 42.00 / USD 59.00 (hard cover)

CHF 60.00 / EUR 50.00 / USD 71.00 (online)

Online versions for institutional purchase Prices subject to change

EUR price for Germany, USD price for USA and Latin America only

ISBN 978-3-318-02669-6 (hard cover)

e-ISBN 978-3-318-02670-2

Fields of Interest:

Nutrition; Gastroenterology; Immunology

A comprehensive review

Nestlé Nutrition Institute Workshop Series, Vol. 79

Nutrition, Gut Microbiota

and Immunity: Therapeutic

Targets for IBD

Editors

James D. Lewis
Frank M. Ruemmele
Gary D. Wu

Nutrition, Gut Microbiota

and Immunity: Therapeutic Targets for IBD

James D. Lewis
Frank M. Ruemmet

Frank M. Rue
Gary D. Wu

KARGER Nestlé

\title{
Contents
}

Preface

Foreword

Contributors

\section{Pathogenesis of IBD}

A Review of the Epidemiology of Inflammatory Bowel Disease with a Focus on Diet, Infections and Antibiotic Exposure: Lewis, J.D.

Current Issues in the Design of Clinical Trials in IBD: Feagan, B.G.

The Intestinal Microbiota in Inflammatory Bowel Diseases: Sartor, R.B.

Genetics and Innate and Adaptive Immunity in IBD: Zanello, G.; Kevans, D.; Goethel, A.; Silverberg, M.; Tyler, A.; Croitoru, K.

Interplay of Nutrients and Microbial Metabolites in Intestinal Immune Homeostasis: Distinct and Common Mechanisms of Immune Regulation in the Small Bowel and Colon: Perrigoue, J.;

Das, A.; Mora, J.R.
Manipulating the Gut Microbiome as a Therapy for IBD

Diet, the Gut Microbiome and the Metabolome in IBD: $W u$, G.D.

Antibiotics, Probiotics and Prebiotics in IBD: Bernstein, C.N.

Fecal Microbiota Transplantation: An Interest in IBD? Kahn, S.A.; Goeppinger, S.R.; Rubin, D.T.

\section{The Future of Nutrition in IBD}

Enteral Nutrition as Treatment Option for Crohn's Disease: In Kids Only? Ruemmele, F.M.; Pigneur, B.; Garnier-Lengliné, H.

Effects of Exclusive Enteral Nutrition on Bone Mass, Linear Growth and Body Composition in Children with Crohn's Disease: Sylvester, F.A.

Exclusive Enteral Nutrition: Clues to the Pathogenesis of Crohn's Disease: Levine, $A$

Current State of the Art of Medical Foods: Blum, S.; Brito, F.

IBD Therapy: New Targets and Unmet Needs: Colombel, J.-F. 


\section{Order Form}

\section{Nestlé Nutrition Institute Workshop Series}

ISSN $1664-2147$

e-ISSN 1664-2155

In 2011, the two book series Nestlé Nutrition Workshop Series: Pediatric Program and Nestlé Nutrition Workshop Series: Clinical \& Performance Program have been merged to form the Nestlé Nutrition Institute Workshop Series. One of the major components of this series is the organization of workshops and the publication of the proceedings. Each workshop focuses on the latest findings, the controversies and further research needs concerning various topics in nutrition.
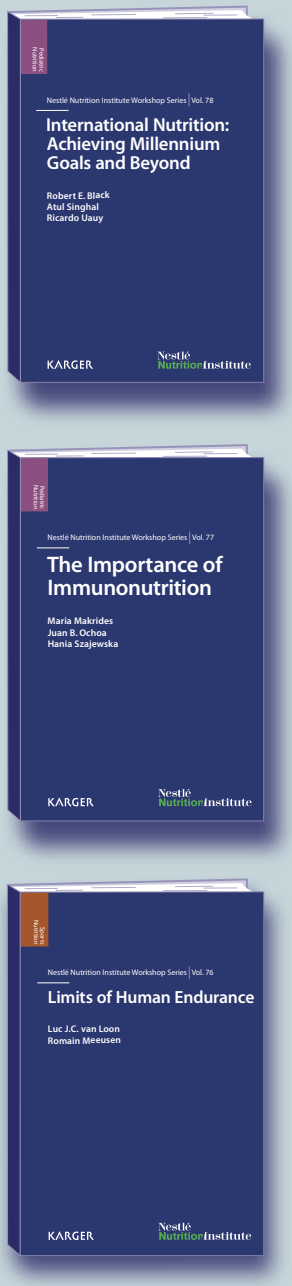

Vol. 78

International Nutrition: Achieving Millennium Goals and Beyond

Editors: Black, R.E. (Baltimore, Md.); Singhal, A. (London);

Uauy, R. (Santiago)

XVI + 166 p., 15 fig., 20 tab., 2014

CHF 50.00 / EUR 42.00 / USD 59.00 (hard cover)

CHF 60.00 / EUR 50.00 / USD 71.00 (online)

ISBN 978-3-318-02530-9 (hard cover)

e-ISBN 978-3-318-02531-6

Vol. 77

The Importance of Immunonutrition

Editors: Makrides, M. (North Adelaide, S.A.); Ochoa, J.B.

(Florham Park, N.J.); Szajewska, H. (Warsaw)

XVI + 174 p., 23 fig., 11 tab., 2013

CHF 50.00 / EUR 42.00 / USD 59.00 (hard cover)

CHF 60.00 / EUR 50.00 / USD 71.00 (online)

ISBN 978-3-318-02446-3 (hard cover)

e-ISBN 978-3-318-02447-0

Vol. 76

Limits of Human Endurance

Editors: van Loon, L.J.C. (Maastricht); Meeusen, R. (Brussels)

XIV + 130 p., 17 fig., 9 tab., hard cover, 2013

CHF 50.00 / EUR 42.00 / USD 59.00 (hard cover)

CHF 60.00 / EUR 50.00 / USD 71.00 (online)

ISBN 978-3-318-02408-1 (hard cover)

e-ISBN 978-3-318-02409-8

Online versions are for institutional purchase

Prices subject to change

EUR price for Germany, USD price for USA and

Latin America only
Nestlé Nutrition Institute Workshop Series

\section{Please send}

copy/ies: Vol. 79: Nutrition, Gut Microbiota and Immunity: Therapeutic Targets for IBD CHF 50.00 / EUR 42.00 / USD 59.00 (hard cover) ISBN 978-3-318-02669-6 (hard cover) e-ISBN 978-3-318-02670-2

_ copy/ies:

ISBN 978-3-318-

The book series Nestlé Nutrition Institute Workshop Series on continuation beginning with vol.

All Karger series are available on continuation. Each new volume will be sent upon publication until order is countermanded.

For easy ordering or further information about the series log on to: www.karger.com/nniws

Postage and handling free with prepayment

Payment

Please charge this order to my credit card

$\bigcirc$ American Express $\bigcirc$ Diners

MasterCard $\bigcirc$ visa

Card No.

Exp. date:

CVV/CVC:

$\bigcirc$ Check enclosed $\bigcirc$ Please bill me

Name/Address:

Date:

Signature:

Orders can be placed at agencies, bookstores, directly with the publisher, or with any Karger distributor.

S. Karger AG, P.O. Box, 4009 Basel (Switzerland)

Fax +41 6130612 34, E-Mail orders@ karger.com

USA: S. Karger Publishers, Inc., 26 West Avon Road,

P.O. Box 529, Unionville, CT 06085 (USA),

Toll free: +1-800-828-5479

Germany: S. Karger GmbH, 79095 Freiburg

France: Librairie Médi-Sciences, 75007 Paris Japan: Karger Japan, Inc., Tokyo 105-0012

South East Asia, China and Taiwan: Karger China,

Beijing 100020

For details and further representatives

and agencies see www.karger.com/worldwide

\section{www.karger.com/nniws}

\section{KARGER}

To be ordered through: 